\title{
EDGE Glued Panels Grading through Transversal Vibration Testing
}

\author{
Carlito Calil Neto ${ }^{1}$, Felipe Arroyo ${ }^{2}$, Victor Almeida De Araujo ${ }^{3}$, André Luís Christoforo ${ }^{2, *}$, \\ Francisco Antonio Rocco Lahr ${ }^{4}$, Carlito Calil Junior ${ }^{4}$
}

\author{
${ }^{1}$ Wood and Timber Structures Laboratory (LaMEM), São Carlos Engineering School, São Paulo University - USP, Av. Trabalhador \\ São-carlense, Centro, zip code, São Carlos, SP, Brazil \\ ${ }^{2}$ Centre for Innovation and Technology in Composites - CITeC, Department of Civil Engineering (DECiv), Federal University of São \\ Carlos, São Carlos, Brazil \\ ${ }^{3}$ Research Group LIGNO of UNESP-Itapeva, Department of Forest Sciences, School of Agriculture Luiz de Queiroz of University of São \\ Paulo (ESALQ/USP), Piracicaba, Brazil \\ ${ }^{4}$ Department of Structures Engineering (SET), Engineering School of São Carlos (EESC), São Paulo University (USP), São Carlos, Brazil
}

\begin{abstract}
The Edge-Glued Panel is produced using sawn wood, i.e., lumber, with or without butt joints and edge-glued lumber. It can be composed with one layer, but the most common is with three layers (two external longitudinal and one transversal). This panel is used in Europe for furniture and forms of concrete structures. The resin applied in the gluing is based on urea-formaldehyde and phenol-formaldehyde. Due to the importance of this panel, this research aims to analyze the use of Transversal Vibration techniques for EGP grading. For this purpose, twelve EGP panels of three layers were produced and tested in order to determine the modulus of elasticity and modulus of rupture in static bending and dynamic modulus. The results showed nonexistent correlations among the dynamic modulus of elasticity with EGP density and between the modulus of rupture in static bending with the dynamic modulus, providing just a good correlation between statistic and dynamic modulus of elasticity.
\end{abstract}

Keywords Wooden panel, Nondestructive test, Transverse vibration, Panel classification

\section{Introduction}

Since 1990s, the solid wood material started to be more stable like in the panel industry and to be used in a faster and more practical manner in the furniture industry as compared to the past with the aid of the developing technology [1].

The Edge-Glued Panel or EGP is formed by laterally glued lumber, with or without end-grain joints [2]. In addition to having the properties of wood, the EGPs have a more heterogeneous structure than solid wood because of the style of cutting solid laths, which come together to form panels [3]. Edge-glued panels are manufactured through the lateral gluing with synthetic adhesives of wooden lathes with width from 30 to 50 millimeters and thickness from 15 to 30 millimeters [4], i.e., they are created from narrow strips of lumber that are glued together under pressure [5]. EGP composition can contain one layer, however, the most popular solution is the three-layer panel whose two external layers are longitudinal and the central layer is transversal [2]. The application of flat edge joining's at a $90^{\circ}$ angle from any

* Corresponding author:

alchristoforo@gmail.com (André Luís Christoforo)

Published online at http://journal.sapub.org/ijme

Copyright (C) 2016 Scientific \& Academic Publishing. All Rights Reserved joining application in side-by-side of long, narrow wooden strips restrict the mechanical resistance of the raw materials in the production of edge-glued panels.

In relation to its raw material, the EGP generally uses wood from planted forests, e.g., pine [6, 7], eucalypt [8, 9], etc. The adhesives applied in gluing stages are generally based on urea-formaldehyde or phenol-formaldehyde [2]. Due to EGP is not being harmful to human health and the environment, the importance of this material is increased [9].

During 1998 to 2007, the Brazilian EGP production presented growth rate around $97 \%$, which was justified by the growing produced volume from 255,000 to $503,000 \mathrm{~m}^{3}$ [10]. In contrast, [1] evaluate that the total European EGP production is reported to be approximately 2 to 2.5 million $\mathrm{m}^{3} /$ year.

The edge-glued panels are versatile in that they can be manufactured for specific end uses, or made as standard-sized blanks [11]. This product has been very applied in Europe for the manufacturing of furniture and concrete forms for structures [2]. Many furniture companies utilize EGPs in products such as table tops, bed or chest panels, and doors. This furniture application for EGP is also quoted by [1], [4] and [7].

Key advantages of edge-glued panel production include the relatively low cost of equipment, potential use of smaller 
diameter stems, utilization of less valuable grades of lumber, flexibility in panel product sizes, and the opportunities to sell within established local markets [5].

Nondestructive evaluation of physical properties of wood has its origin in the need to solve practical problems without destruction of the integrity of the examined object, and scientific methods became possible in the early 1900s with the development of theory of elasticity and of the instrumentation for measurement of wood properties [12]. Measurement of mechanical properties of structural composite products is an emerging technology that operates analogously to the machine grading process [13].

Nondestructive techniques also enable wood maintenance through mapping of decayed areas without the need to remove parts of the structure [14].

[15] list that the most common methods of nondestructive evaluation applies the technologies of $\mathrm{x}$-ray, ultrasound, eddy-current, vibration analysis, acoustic emission, etc. Transverse vibrations and stress waves can be used to estimate bending stiffness $[16,17]$. [18] state the nondestructive techniques are based on the use of an estimator to verify the mechanical properties of wood. Thereby, the nondestructive evaluations based on vibration and ultrasound techniques are used in scientific area to determine the physical and mechanical properties of woods [15]. These transverse vibration techniques have received considerable attention for nondestructive testing applications in wood industry [19].

This method consists of a stroke application in a bi-supported wood piece, whose supports are a lamina in an extreme and a load cell in the other end piece. The piece will vibrate at its natural vibration frequency up to this vibration ceases due to the damping. The load cell captures the vibration of the beam and transfers the signal to a circuit, which amplifies and filters it, and then, this amplified signal is digitized and sent to a computer to determine the frequency of the oscillating signal [20].

In the transverse vibration method, the natural vibration frequency of any material is correlated to its static bending. As a consequence, appropriate mathematical relations among these properties and the properties of static bending and elasticity can be obtained through statistical regression analysis [21].

To illustrate these methods of transverse vibration (Fig. 1), an analogy can be drawn between the behavior of a vibrating beam and the vibration of a mass that is attached to a weightless spring and internal damping force [19, 22]. According to [20], this natural vibration frequency of wood will depends on: the modulus of elasticity of wood, span between the two supports, wood density, and the type of support.

In the Figure 1, the mass $M$ is supported from a rigid body by a weightless spring whose stiffness is denoted by $K$. Internal friction or damping is represented by the dashpot $D$. A forcing function equaling $P_{0} \sin \omega t$ or zero is applied for forced or free vibration, respectively. When $M$ is set into vibration, its equation of motion can be expressed by the following $[19,22]$ :

$$
\begin{aligned}
& M\left(\frac{d^{2} x}{d t^{2}}\right)+D\left(\frac{d x}{d t}\right)+K \cdot x=P_{0} \cdot \sin (\omega \cdot t) \\
& { }^{M} \underline{x}_{0} \underline{x}_{0} P_{0} \cdot \sin (\omega \cdot t)
\end{aligned}
$$

Figure 1. Mass-spring dashpot vibration (left) and transversely vibrating beam (right). Adapted from [19] and [22]

According to these last aforementioned literatures, the equation 1 can be solved for either $K$ or $D$, and a solution for $K$ will lead to an expression for modulus of elasticity $E$ or $M O E$ for a beam simply supported at its ends:

$$
M O E=\frac{f_{r}^{2} \cdot W \cdot L^{3}}{2.46 \cdot I \cdot g}
$$

In this equation $2, f_{r}$ is natural frequency in Hertz, $W$ is beam weight in kilograms, $L$ is beam span in meters, $I$ is beam moment of inertia in meter to fourth power, and $g$ is the acceleration due to gravity, i.e., $9.8 \mathrm{~m} / \mathrm{s}^{2}[19,22]$. The Figure 2 shows the scheme of a machine to determine $M O E$ by transverse vibration.

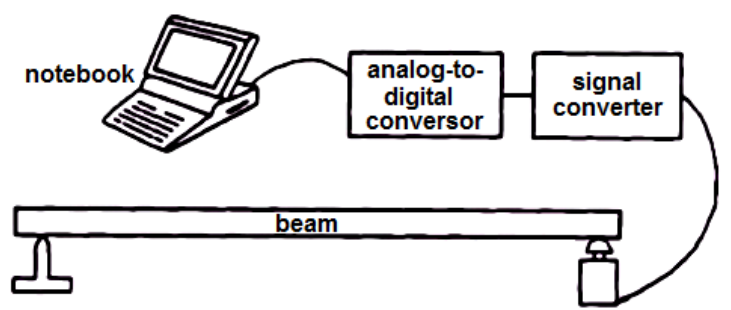

Figure 2. Machine to determine Modulus of Elasticity by transverse vibration

Considering the current Brazilian National Program of Timber Quality (PNQM - Programa Nacional de Qualidade da Madeira) applied to plywood, an important structural wood-based composite, the natural variability of strength and stiffness properties of these panels and the rational utilization of wood species from planted forests are two important topics for the industrial awareness about nondestructive grading (classification) of plywoods to be used.

Through the importance of these wooden products for domestic and international markets, this paper aims to present an experimental study of the properties of strength and stiffness of three-layered Edge-Glued Panels with emphasis on the utilization of transverse vibration for nondestructive grading. 


\section{Material and Methods}

The selected boards for this research were 12 three-layered edge-glued panels. The EGP composition is formed by two external longitudinal layers and a transverse central layer, both in Pine wood with 7-millimeter thick. Battistella industry manufactures these edge-glued panels using melamine adhesive, which are known by the commercial name IstelaPlac. These EGP boards with 150-millimeter width by 2050-millimeter length were tested in static bending in three points, to obtain the modulus of elasticity in static bending ( $M O E$ or $E$ ) and the modulus of rupture in static bending $(M O R)$. To evaluate the validity of the utilization of the nondestructive grading method by transverse vibration (TV), the wooden pieces of EGP were classified through the Metriguard equipment for transverse vibration.

In transverse vibration grading, the equipment E-Computer model 340 from Metriguard was used (Fig. 3). Before the test, the dimensions of transverse section were measured, as well as the lengths of the 12 boards. These EGP boards were tested in a 2000-millimeter span.

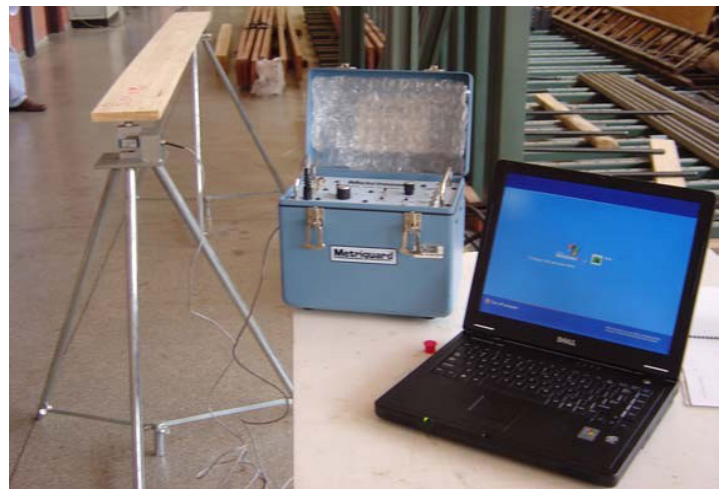

Figure 3. Equipment of transverse vibration used in the tests

Previously, this equipment was calibrated using an aluminum bar of a known MOE. The pieces vibration was produced with the application of a stroke in the center of the span of EGPs.

To verify the accuracy of the results obtained with the transverse vibration technique, tests of static bending were realized. The wood-based panels (EGP) were placed in steel supports with a span of 2000 millimeters. Considering the nominal height of $21 \mathrm{~mm}$, the wooden pieces were bended with a ratio $L / h$ equal to 100 . In a central position between the two supports, a dial indicator was inserted, which has graduation of $0.01 \mathrm{~mm}$ and a maximum limit of $50 \mathrm{~mm}$. A force was applied in the center of EGP beams, in two intensities: 25 and $50 \mathrm{~N}$ (Fig. 4).

The intensity of force was defined with the limitation of the maximum vertical displacement in $L / 200$, considering a modulus of elasticity of $10,000 \mathrm{MPa}$. The modulus of elasticity in static bending relative to the axis of small inertia was determined in the second loading increase, through the following equation:

$$
M O E=\frac{\Delta F \cdot L^{3}}{48 \cdot \Delta v \cdot I}
$$

In Equation 3, $\Delta F$ is the static load in Newton $\left(\mathrm{F}_{2}-\mathrm{F}_{1}\right), L$ is the EGP beam span in millimeters, $\Delta v$ is the displacement increasing in millimeters $\left(\mathrm{v}_{2}-\mathrm{v}_{1}\right)$, and $I$ is the moment of inertia of the transverse section in meters to fourth power $\left(\mathrm{m}^{4}\right)$.

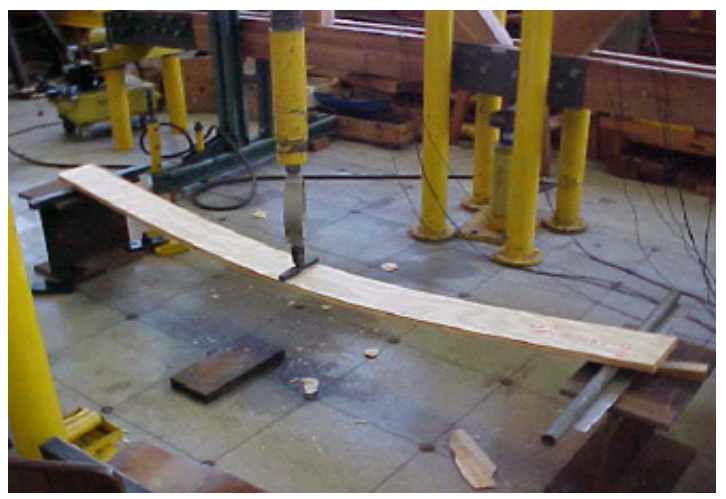

(a)

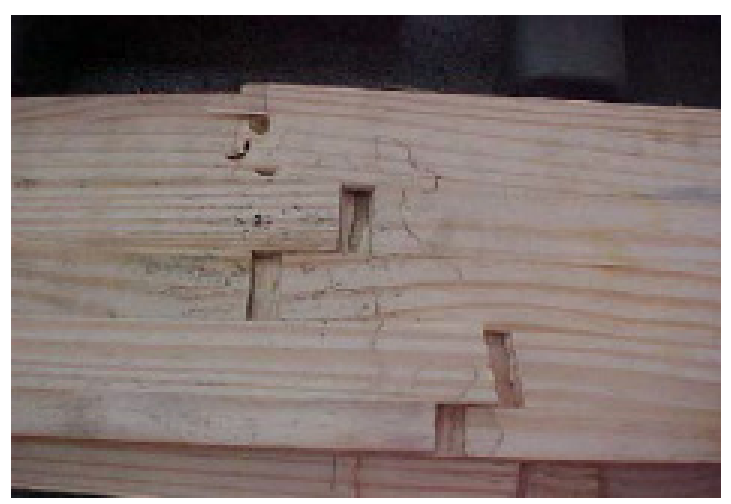

(b)

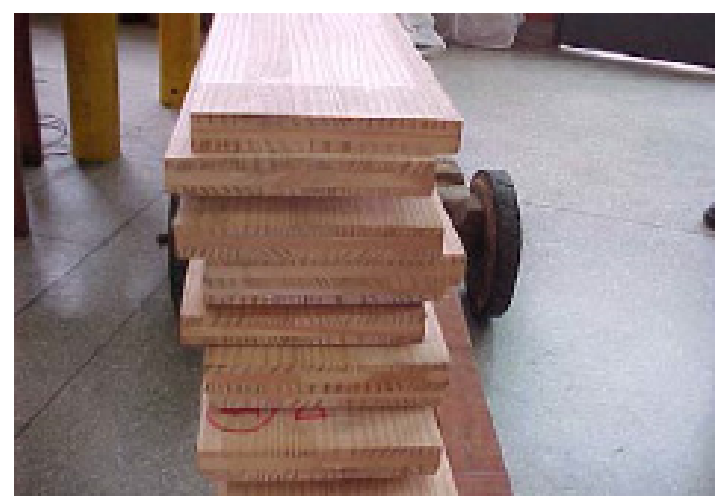

(c)

Figure 4. (a) Static bending test, (b) transverse section of pieces and (c) EGP beams

For each panel, with dimensions $21 \mathrm{~mm} \times 150 \mathrm{~mm} \times$ $2050 \mathrm{~mm}$, it was determined the densities $(\rho)$, modulus of elasticity $\left(\mathrm{MOE}_{\text {static }}\right)$ and modulus of rupture $(\mathrm{MOR})$ with static bending tests and dynamic modulus of elasticity $\left(\mathrm{MOE}_{\text {dynamic }}\right)$ with transverse vibration test. 
Linear regression models were used to verify the possibility of estimating the dynamic modulus of elasticity by the density, the static modulus of elasticity by the dynamic modulus of elasticity and modulus of rupture by the dynamic modulus of elasticity. The quality of the adjustments was evaluated by the determination coefficient $\mathrm{R}^{2}$.

\section{Results and Discussion}

The mean values $(\bar{x})$ and the variation coefficient $(C v)$ results are presented in Table 1, and the obtained results from the linear regression models are graphically presented in Figure 5, 6 and 7 with the respective statistical analysis (equation and $\mathrm{R}^{2}$ determination coefficient).

Of linear regression models tested, it is noted that the density did not appear as good estimator of the dynamic modulus of elasticity of EGP panels. The dynamic modulus of elasticity can be used to estimate the static modulus of elasticity due to the excellent value obtained for the coefficient of determination $\left(\mathrm{R}^{2}=87.7 \%\right)$, but does not show as good estimator for the determination of the bending strength.

Table 1. Properties of the studied pine EGP

\begin{tabular}{ccccc}
\hline Panel & $\boldsymbol{\rho}\left(\mathbf{g} / \mathbf{c m}^{\mathbf{3}}\right)$ & $\begin{array}{c}\mathbf{M O E}_{\text {static }} \\
(\mathbf{G P a})\end{array}$ & $\begin{array}{c}\mathbf{M O E}_{\text {dynamic }} \\
(\mathbf{G P a})\end{array}$ & $\begin{array}{c}\text { MOR } \\
(\mathbf{M P a})\end{array}$ \\
\hline 1 & 594 & 13.14 & 14.58 & 53 \\
2 & 580 & 11.84 & 12.71 & 34 \\
3 & 580 & 13.46 & 14.25 & 60 \\
4 & 580 & 13.79 & 14.25 & 43 \\
5 & 565 & 12.20 & 12.54 & 53 \\
6 & 558 & 12.92 & 13.03 & 30 \\
7 & 565 & 12.00 & 12.73 & 41 \\
8 & 580 & 13.63 & 15.29 & 62 \\
9 & 580 & 14.54 & 15.90 & 61 \\
10 & 594 & 14.46 & 16.09 & 32 \\
11 & 580 & 12.06 & 12.86 & 54 \\
12 & 565 & 13.46 & 14.58 & 49 \\
\hline $\bar{x}$ & 576.75 & 13.13 & 14.07 & 47.67 \\
$C v(\%)$ & 1.97 & 7.14 & 9.10 & 24.04 \\
\hline
\end{tabular}

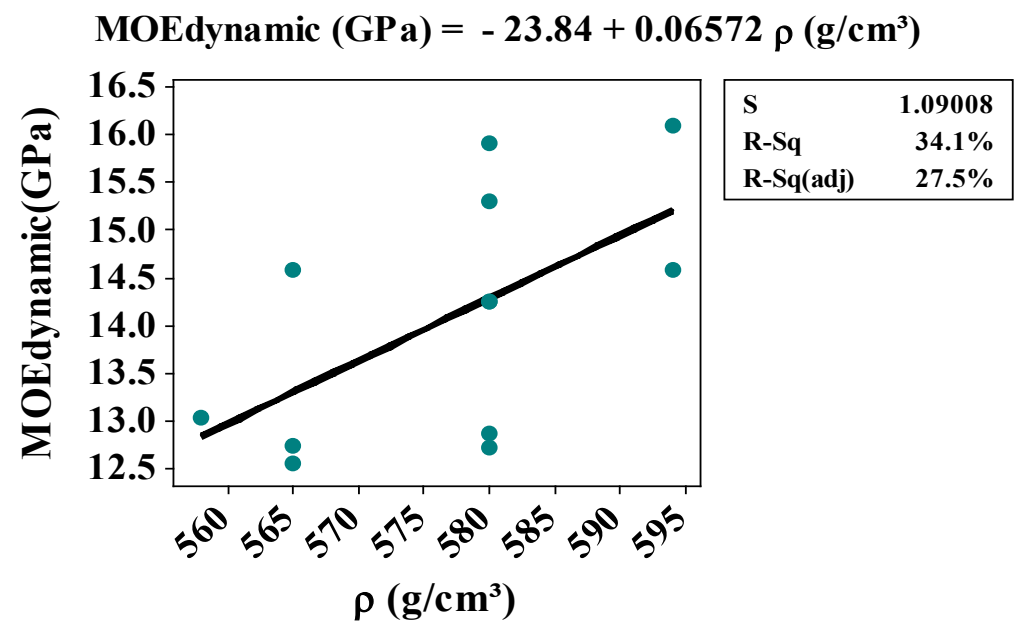

Figure 5. Analysis of linear regression between $\mathrm{MOE}_{\text {dynamic }}$ and density

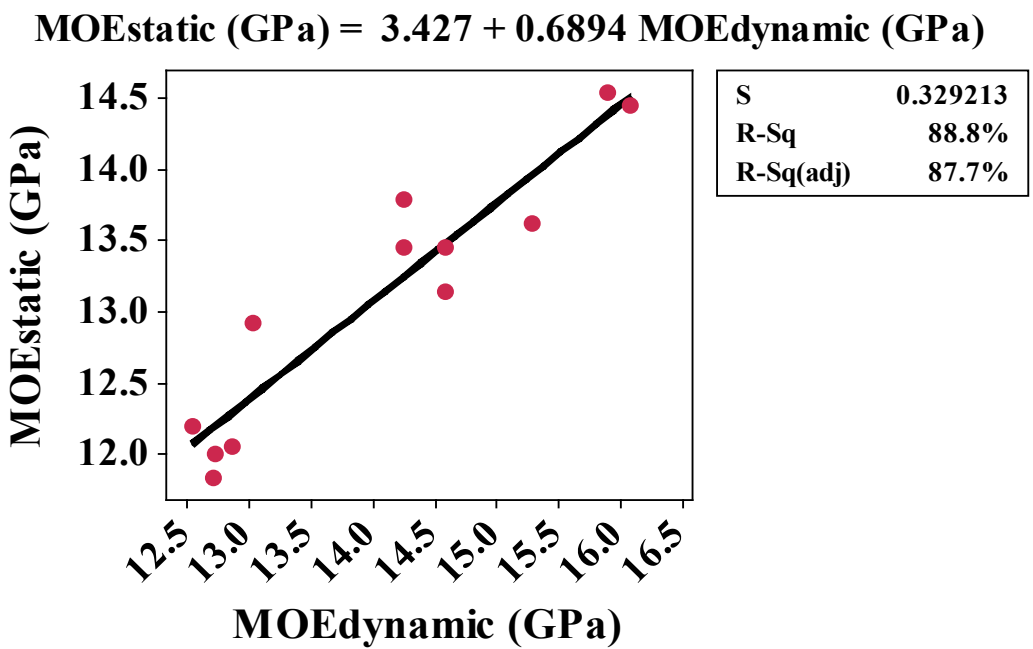

Figure 6. Analysis of linear regression between $\mathrm{MOE}_{\text {dynamic }}$ and $\mathrm{MOE}_{\text {static }}$ 
MOR $($ MPa $)=12.49+2.500$ MOEdynamic $($ GPa $)$

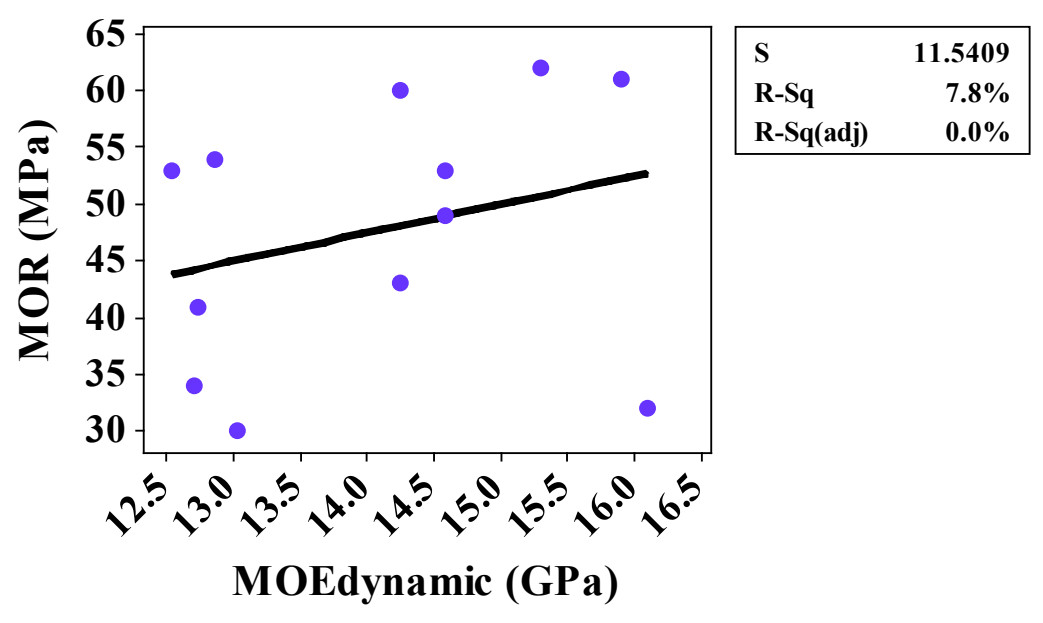

Figure 7. Analysis of linear regression between $\mathrm{MOE}_{\text {dynamic }}$ and $\mathrm{MOR}$

\section{Conclusions}

Through the results and analysis, it was verified that there is no correlation between the dynamic modulus of elasticity and density as well as there is no correlation between modulus of rupture and dynamic modulus of elasticity, and a good correlation between the static and dynamics modulus of elasticity.

Furthermore, the average modulus of elasticity verified by the static bending tests was $13.13 \mathrm{GPa}$ with the standard deviation of $0.9 \mathrm{GPa}$. For the transverse vibration method, the average modulus of elasticity was $14.07 \mathrm{GPa}$ with a standard deviation $1.23 \mathrm{GPa}$. Through the transverse vibration equipment, the determination coefficient $\left(\mathrm{R}^{2}\right)$ was 0.8877 .

Then, the transverse vibration technique is a practical and accurate method for nondestructive grading for EGP panels.

\section{ACKNOWLEDGMENTS}

We are grateful the industry Battistella Indústria $e$ Comércio de Madeiras for the donation of EGP boards used in the tests. The tests were realized in the Laboratory of Woods and Wooden Structures (LaMEM - Laboratório de Madeiras e Estruturas de Madeira) of University of São Paulo (USP - Universidade de São Paulo).

\section{REFERENCES}

[1] Dilik, T.; Erdinler, S.; Kurtoglu, A. Edge glued wood panel technology and an assessment on the development of edge glued wood panel industry. American Journal of Applied Sciences 9 (10): p.1625-1635, 2012.
[2] Mattos, R. L. G.; Gonçalves, R. M.; Chagas, F. B. Painéis de madeira no Brasil: panorama e perspectivas. BNDES Setorial (27): 121-156, 2008.

[3] Sütçü, A. Investigation of parameters affecting surface roughness in CNC routing operation on wooden EGP. BioResources 8 (1): 795-805, 2013.

[4] Del Menezzi, C. H. S.; Nahuz, M. A. R.; Souza, M. R. Utilização de um método combinado de desdobro e secagem para obtenção de madeira serrada de eucalipto destinada à produção de painéis colados lateralmente. Árvore 25 (1): $113-123,2001$.

[5] Nicholls, D. Alaska birch for edge-glued panel production considerations for wood products manufacturers. PNW-GTR-820. USDA. Portland, USA, 2010.

[6] Lopes, M. C.; Muniz, G. I. B.; Matos, J. L. M.; Tanobe, V. O. A.; Chinasso, C. A. F.; Rosso, S. Resistência da linha de cola de painéis de Pinus taeda colados lateralmente com diferentes adesivos. Cerne 19 (4): 613-619, 2013.

[7] Ferraresi, F. A. A.; Cortez-Barbosa, J.; Campos, C. I.; Ferreira, B. S.; De Araujo, V. A.; Gava, M. Effect of wood moisture content in edge glued panel bonding for furniture industry: analysis of shear-stress and rupture in bondline. Advanced Materials Research 1025-1026 (2014): 227-232, 2014.

[8] Martins, S. A.; Del Menezzi, C. H. S.; Ferraz, J. M.; Souza, M. R. Bonding behavior of Eucalyptus benthamii wood to manufacture edge glued panels. Maderas Ciencia y Tecnología 15 (1): 79-92, 2013.

[9] Özkaya, K. The effects of different edge joinings on the resistance of edge glued wooden panels. Technology (Jestech) 14 (2): 53-58, 2011.

[10] Associação Brasileira da Indústria de Madeira Processada Mecanicamente. Estudo Setorial 2008. Curitiba, Brazil, 2008.

[11] Bowyer, J. L.; Kallio, E.; Monson, C. R.; Nicholls, D. L. Standard blanks: a new alternative to hardwood lumber. Forest Products Journal 36 (2): 67-73, 1986. 
[12] Bucur, V. Nondestructive characterization and imaging of wood. Springer-Verlag. Berlin, Germany, 2003.

[13] Beall, F. C. Industrial applications and opportunities for nondestructive evaluation of structural wood members. Maderas Ciencia y Tecnología 9 (2): 127-134, 2007.

[14] Cademartori, P. H. G.; Missio, A. L.; Gato, D. A.; Beltrame, R. Prediction of the modulus of elasticity of Eucalyptus grandis through two nondestructive techniques. Floram 21 (3): 369-375, 2014.

[15] Targa, L. A.; Ballarin, A. W.; Biaggioni, M. A. M. Avaliação do modulo de elasticidade da madeira com o uso de método não-destrutivo de vibração transversal. Engenharia Agrícola (Jaboticabal) 25 (2): 291-299, 2005.

[16] Wang, X., Ross, R. J., Mattson, J. A., Erickson, J. R., Forsman, J. W., Geske, E. A., Wehr, M. A. 2001 Several nondestructive evaluation techniques for assessing stiffness and MOE of small-diameter logs. Research Paper FPL-RP-600. USDA. Madison, USA, 2005.

[17] Vikram, V.; Cherry, M. L.; Briggs, D.; Cress, D. W.; Evans,
R.; Howe, G. T. Stiffness of Douglas-fir lumber: effects of wood properties and genetics. Canadian Journal of Forest Research 41: 1160-1173, 2011.

[18] Carrasco, E. V. M.; Azevedo Junior, A. P. Avaliação não-destrutiva de propriedades mecânicas de madeiras através de ultra-som-fundamentos físicos e resultados experimentais. Cerne 9 (2): 178-191, 2003.

[19] Ross, R. J.; Pellerin, R. F. Nondestructive testing for assessing wood members in structures: a review. Gen. Tech. Rep. FPL-GTR-70. USDA. Madison, USA, 1994.

[20] Carreira, M. R.; Dias, A. A. Avaliação da rigidez à flexão de toras de madeira por meio de vibração transversal. Cadernos de Engenharia de Estruturas 11 (53): 75-79, 2009.

[21] Calil Junior, C; Miná, A. J. S. Vibração transversal: Um método eficiente para classificação de peças estruturais de madeira. Agriambi 7 (2): 335-338, 2003.

[22] Ross, R. J.; Wang, X.; Hunt, M. O.; Soltis, L. A. Transverse vibration technique to identify deteriorated wood floor systems. Experimental Techniques 26 (4): 28-30, 2002. 